\title{
JOB SATISFACTION OF A SELECTED GROUP OF HOSPITAL DIETITIANS
}

\author{
LEONIE E. VAN HEERDEN \\ UNIVERSITY OF STELLENBOSCH
}

\begin{abstract}
OPSOMMING
Die werkstevredenheid van hospitaaldieetkundiges word ondersoek na aanleiding van die interverwantskap van verskillende aspekte wat tot 'n beter verklaring daarvan kan lei. Die algemene werkstevredenheid, werkstevredenheid met spesifieke aspekte van die werk en persoonlikheidstrekke van dieetkundiges word met bestaande skale en 'n ontwikkelde meetmiddel ondersoek. Die studie is ' $n$ bydrae tot die verdere verklaring en moontlike bevraagtekening van die werkstevredenheid van professionele vroue in 'n bepaalde werksomgewing - in hierdie geval professionele dieetkundiges in hospitale.
\end{abstract}

The hospital with its dual line of authority, formal and informal, provides a unique organisational structure for the study of human behaviour. Normal lines of communication are often not possible because of the long history of tradition and status in the hospital and the fact that the physician as an authority is not usually a hospital employee.

In the execution of dietary treatment the dietitian has to cope simultaneously with peer, subordinate and supervisory relationships. According to Wagner and Dreyer (1962) many of these relationships are unspoken and often conflicting, superimposed on an already ill-defined role of dietary management and patient care.

The nurse on the other hand accepts the medical authority and derives satisfaction from the execution of functions to meet the situationally derived needs of the patient. The meaningfulness of serving and helping others and the type of personality that chooses nursing as a profession, is demonstrated in a study by Alexander (1962). In this study nurses are seen as having high Nurturance needs, low Achievement needs and relatively weak needs for Autonomy as measured by the Edwards Personal Preference Schedule.

This is different from the personality traits of the dietition who was found by Cleveland (1963) and Hornaday (1963) as preferring to direct others and finding fulfilment of prestige and status needs through opportunities to influence and supervise others. The hospital

\footnotetext{
* Data taken from a dissertation submitted in partial fulfillment of the requirements for the degree of Doctor of Philosophy at Cornel University, New York, September 1971
} 
dietitian is also seen as more likely to express open and direct aggression to superiors (Wagner \& Dreyer, 1962) and will probably handle frustrating situations differently depending on the social status of the individual involved.

In a study on the job satisfaction of hospital dietitians Tansiongkun (1968) investigated the relationship between the dietitian's managerial level and need fulfilment as influenced by the size and type of hospital and the age and years of experience of the subject. She used Porter's scale (Porter, 1962) to determine the importance an individual attaches to the attainment of Security, Social, Esteem, Autonomy and Self-actualization needs. Since Tansiongkun used a scale developed for men in managerial positions, there is some doubt as to whether the differences found, could be attributed to the scale itself or to sex differences.

The influence of work environment on job satisfaction is undoubtedly determined by the situation in which the relationship is being measured. Each work situation is to some extent unique and will therefore provide a different set of variables that could be related.

The dietary department in a hospital differs from all the other departments, since it can be classified under the realms of both management and clinical services. Virtually all other departments in the hospital have their primary function in either management or patient care (McGibony, 1969). Employees in the dietary department may be unskilled, skilled or professional. This brings about a very loosely knit, unstable work group that frequently tends to fall apart, especially in the case of large institutions where there is a high turnover rate.

The adjustment and satisfaction of the dietitian in the hospital dietary department are concerns of administrators, educators and professionals alike. The present study is not only directed at satisfaction per se, but an attempt is also made to gain more understanding of the dietitian's attitudes and feelings within the work environment. This was done by determining the general job satisfaction of dietitians and the extent to which job satisfaction is affected by the moderator variables chosen for this study. Correlation coefficients were used to express the relationship of personality variables to general job satisfaction and to satisfaction with specific aspects of the job. 
A random sample of 500 dietitians with hospital addresses was drawn from the list of hospital employed dietitian members of the American Dietic Association. Each subject was mailed a set of material consisting of:

a) questions related to demographic data,

b) a General Job Satisfaction scale (Hoppock, 1935),

c) a Job Factor scale developed by the author and

d) the Adjective Check List (ACL) Personality scale (Gough \& Heilbrun, 1965).

Usable questionnaires were returned by $391(78 \%)$ of the dietitians.

Questions related to demographic data included age, marital status, education, salary and type of hospital. These were regarded as moderator variables and were correlated with general job satisfaction in the final analysis.

The General Job Satisfaction scale (Hoppock's JSB) consists of four questions regarding the subject's general feelings about her job. This specific form has been developed due to continuous changes made through the years to facilitate its use. The score can be expressed either by a weighted index of job satisfaction or a simple average of the values assigned to each question. Since these two methods correlate highly, the latter is preferred due to its ease of computation.

The Job Factor scale consists of a seven-point Likert type questionnaire, on which the subject had to indicate her satisfaction or dissatisfaction with various aspects of the following six job factors: "Work conditions", "Supervision", "Your Work Group", "Policies and Practices", "Your Job Performance". The internal consistency of the scale is indicated by a split-half reliability coefficient of 0,93 .

The ACL Personality scale consists of 300 adjectives from which the subject is asked to check those that he feels apply to him. The ACL provides for scores on twenty-three scales or indices. The first four scales are mostly related to the adjective checking procedure and include the Number of Adjectives checked, since a correction is made for subjects that check more or less adjectives; a Defensiveness scale which measures the guardedness or defensiveness with which a subject completes the check list; a scale for the Number of Favourable Adjectives checked, on which subjects who tend to check a greater number of 
favourable adjectives are seen as different from those who check less and a scale for the Number of Unfavourable Adjectives checked, which is just the opposite of the previous scale. The next four scales are specifically concerned with variables of social interaction, personal adjustment and personal effectiveness, and are Achievement, Dominance, Endurance, Order, Intraception, Nurturance, Affiliation, Heterosexuality, Exhibition, Autonomy, Aggression, Change, Succorance, Abasement and Defence.

Scores on the Job Factor scale measuring satisfaction with particular aspects of the job were correlated with the General Job Satisfaction score.

\section{RESULTS AND DISCUSSION}

The mean General Job satisfaction score for the total sample was 21,9. Since the maximum possible score was 28 , the actual cut-off point for the distinction between satisfied and dissatisfied would be 14. Dietitians in this sample can therefore be considered very satisfied with their jobs in general. For the purposes of this study and to facilitate discussion, subjects falling below the mean of 21,9 were classified as dissatisfied $(43,5 \%)$ and those above the mean as satisfied $(56,5 \%)$.

Chi-square values were computed to determine significant differences between satisfied and dissatisfied dietitians with respect to the moderator variables. Type of occupation was not found to discriminate between the groups, but age and salary were found to be significant $(p<0,05)$. The age curve showed a high level of satisfaction in the early twenties, a rapid decline to a low level of satisfaction between twenty-five and fifty years of age, with a gradual incline to reach a peak in the over fifty years age group. No significant differences were found on the basis of education or marital status.

Type of hospital discriminated between satisfied and dissatisfied dietitians. The highest percentage of dissatisfied dietitians were found in the Children's and Psychiatric hospitals, whereas dietitians in general hospitals, providing medical and surgical treatment, were more satisfied.

Correlations between scores on the Job Factor Scale and the General Job Satisfaction score are given in Table 1. The range of coefficients is comparable to those shown in other studies on the relationship between General Job Satisfaction and satisfaction with specific aspects of the job. (Crites, 1969; Carroll, 1969). 


\section{TABLE 1}

\section{RELATION BETWEEN GENERAL JOB SATISFACTION AND JOB FACTOR SCORES}

\begin{tabular}{|c|c|}
\hline Job Factors & Correlation Coefficients* \\
\hline Work Conditions & 0,38 \\
\hline Supervision & 0,57 \\
\hline Your Work Group & 0,59 \\
\hline Policies and Practices & 0,51 \\
\hline Your Job & 0,65 \\
\hline Your Job Performance & 0,65 \\
\hline
\end{tabular}

The general attitude of dietitians towards particular aspects of their job was determined by the Job Factor scale. Each job factor had a different number of questions relating to aspects of the factor. Possible maximum scores for the different factors therefore were different as reflected by Table 2. In order to compare the scores on the job factors, the mean on the seven-point scale, known as the "grand mean" was computed. This differed from the total means on the job factors which are computed by totalling across all answers to the questions on the factor. The "grand means" are also given in Table 2. From the table it can be seen that relatively low satisfaction shows a relationship with the physical and social environment of the job, while high satisfaction is related to the intrinsic aspects of the jobs .

$\underline{\text { TABLE } 2}$

MEAN SCORE ON JOB FACTOR SCALE

\begin{tabular}{|l|c|c|c|c|}
\hline \multicolumn{1}{|c|}{ Job Factor } & Mean & SD & $\begin{array}{c}\text { Possible range } \\
\text { of scores }\end{array}$ & $\begin{array}{c}\text { Grand } \\
\text { mean }\end{array}$ \\
\hline Work Conditions & 28,9 & 7,9 & $6,0-42,0$ & 4,8 \\
Supervision & 36,1 & 8,2 & $7,0-49,0$ & 5,2 \\
Your Work Group & 39,3 & 6,9 & $7,0-49,0$ & 5,6 \\
Policies and Practices & 33,8 & 6,4 & $6,0-42,0$ & 5,6 \\
Your Job & 34,2 & 6,8 & $6,0-42,0$ & 5,8 \\
Your Job Performance & 47,3 & 7,0 & $8,0-56,0$ & 5,9 \\
\hline
\end{tabular}

\section{Work conditions}

Noise in the department, the lay-out of the hospital to facilitate service and the amount of privacy in the work area, were the most dissatisfying aspects for this sample of dietitians. 
Everyone was generally satisfied with the cleanliness and hygiene as well as the attractiveness of the department.

\section{Supervision}

All dietitians seemed satisfied with the amount of recognition that they received from their supervisors. Although questions under the "supervision" factor were concerned with the supervisory function, the answers in some way might have been related to the subject's feelings about the personality of the supervisor. Subordinates who liked their supervisors described them differently from those who had a dislike of their supervisors. Personality dislikes may to some extent have contaminated the results on this scale.

\section{Your work group}

The extent to which personalities are compatible is often manifested in satisfaction with the work group. The work group and interpersonal relations have proved an important factor contributing to the job satisfaction of women (King, 1961 and Lewis, 1968). This seems to indicate that the meaningfulness of the job is often more related to the relationships that are made possible than to the extent that success or promotion is achieved. Walt (1962) found that this was especially true for single women in professional positions.

The present study indicated that the work group in the dietary department may differ considerably from one hospital to another. An only dietitian may for instance have limited contact with other professionals and be largely in contact with fellow food service employees. A larger hospital on the other hand may give more opportunities for professional contact.

\section{Policies and practices}

Aspects of this factor that contributed to dissatisfaction was remuneration, the extent to which rules and regulations were enforced, and the fairness with which hospital employees were evaluated. Everyone in general seemed satisfied with the fringe benefits provided by the hospital. Contrary to expectations dietitians were very satisfied with their working hours, but not as satisfied with their pay. 


\section{Your job}

Questions on this factor related to the subject's feelings about her job in general. Since the present job is indicated, this does not mean the chosen profession, but rather the job situation that the dietitian found herself in at the time of the study.

Dietitians seemed satisfied with most aspects of their jobs, except the possibilities seen for future advancement. This may be explained by the fact that most dietitians in this sample were older and therefore looking forward to retirement. The possibilities for future advancement had little meaning for them as most had already achieved reasonably high positions.

\section{Your job performance}

From Table 1 it is clear that dietitians were most satisfied with this factor. On the whole it can be said that they had the knowledge required for the job, that they had the health and work capacity to do a good job and that they had an understanding of the job.

The measurement of satisfaction with "Your Job Performance" has little if any relation to the actual measurement of productivity or performance. Although good job performance is sometimes identified as a result of satisfaction with the job, this is not always the case. In considering the professional in a professional job capacity, judgement of own job performance may be some indication of the level of performance or professionalism maintained.

\section{Personality profiles}

A feeling of satisfaction and accomplishment is generally a combination of psychological, physiological and environmental circumstances. Therefore, apart from the results found from the General Job satisfaction and Job Factor scales, personality profiles of dietitians were also drawn.

Computation of the means on each personality scale for the total sample resulted in a particular personality profile for this group of dietitians. They appeared to be people with high needs for Dominance, Endurance and Achievement, but low needs for Change, Affiliation and Aggression. High scores on the social interaction scales are usually expected from professionals. These dietitians had high scores on Personal Adjustment and Self-Confidence, but were significantly low on Self Control. This seems to be one of the distinguishing characteristics of the hospital dietitian's profile. Only the headstrong characteristic of the low scorer on Self-Control seems to fit with the rest of the dietitians' profile. The other 
characteristics, such as the tendency to complain and to be argumentative, do not seem to describe the hospital dietitian. This inconsistency may be due to contra-indicative adjectives in the scale.

The mean scores on the personality scales for the total sample ranged from 42,6 to 59,2. Since 50,0 is the normalised standard score, the deviation is within the expected normal range. In general these scores depicted a personality who is strong-willed, persevering and ambitious, while also being considerate and responsive to others.

$\underline{\text { TABLE } 3}$

MEANS, STANDARD DEVIATIONS AND DIFFERENCES FOR SATISFIED AND DISSATISFIED DIETITIANS ON PERSONALITY VARIABLES (ACL PERSONALITY SCALE)

\begin{tabular}{|c|c|c|c|c|c|}
\hline & \multicolumn{2}{|c|}{$\begin{array}{c}\text { Dissatisfied } \\
\mathrm{N}=170\end{array}$} & \multicolumn{2}{|c|}{$\begin{array}{l}\text { Satisfied } \\
N=221\end{array}$} & \multirow[t]{2}{*}{$\mathrm{t}-$ Value } \\
\hline & Mean & SD & Mean & SD & \\
\hline Number Checked & 53,2 & 8,6 & 55,8 & 7,5 & 3,1 \\
\hline Defensiveness & 53,2 & 10,6 & 57,6 & 9,4 & 4,2 \\
\hline Favourable Adjectives & 45,2 & 8,6 & 42,9 & 6,7 & 2,9 \\
\hline Unfavourable Adjectives & 52,1 & 10,2 & 55,6 & 10,0 & 3,4 \\
\hline Self-Confidence & 56,8 & 9,2 & 58,5 & 8,6 & 2,0 \\
\hline Self-Control & 42,6 & 8,7 & 42,6 & 9,6 & $0,0^{*}$ \\
\hline Lability & 53,0 & 9,3 & 56,2 & 8,6 & 3,6 \\
\hline Personal Adjustment & 55,7 & 9,8 & 59,6 & 9,0 & 4,1 \\
\hline Achievement & 53,6 & 10,8 & 57,0 & 9,7 & 3,2 \\
\hline Dominance & 57,9 & 7,6 & 60,1 & 6,6 & 3,0 \\
\hline Endurance & 57,8 & 8,1 & 59,8 & 7,1 & 2,6 \\
\hline Order & 53,6 & 9,9 & 55,3 & 9,1 & 1,7 \\
\hline Intraception & 49,6 & 9,4 & 52,6 & 7,0 & 3,2 \\
\hline Nurturance & 46,4 & 10,8 & 50,8 & 8,9 & 4,4 \\
\hline Affiliation & 42,8 & 10,8 & 43,8 & 8,8 & $1,0 *$ \\
\hline Hetrosexuality & 44,5 & 9,4 & 45,7 & 9,4 & $1,2 *$ \\
\hline Exhibition & 47,7 & 9,2 & 47,0 & 8,4 & $0,8^{*}$ \\
\hline Autonomy & 49,6 & 10,4 & 48,1 & 8,5 & 1,6 \\
\hline Aggression & 43,4 & 9,2 & 42,2 & 8,8 & $1,2 *$ \\
\hline Change & 44,8 & 8,8 & 42,6 & 7,1 & 2,7 \\
\hline Succorance & 48,1 & 10,6 & 45,3 & 8,6 & 2,8 \\
\hline Abasement & 50,7 & 9,4 & 50,4 & 8,2 & $0,2 *$ \\
\hline Defence & 53,8 & 9,4 & 53,1 & 9,6 & $0,7 *$ \\
\hline
\end{tabular}

$*=$ Not significant at, 05 level. 
Further explanation of the extent to which job satisfaction is a function of personality is given by the fact that subjects found to be satisfied with their jobs differed from those who were dissatisfied (Table 3). Job satisfaction, however, was not only measured in terms of overall satisfaction with the job, but also in terms of satisfaction with specific aspects of the job as measured by the Job Factor scale. The correlation coefficients indicating the relationship between personality variables and the job factors are given in Table 4. Although these correlations are not high, they are always in the expected direction, that is, a high score on a desirable personality characteristic is related to a positive job attitude and gives a positive correlation with job satisfaction, whereas a desirable characteristic means a low score on the personality scale and correlates negatively with job satisfaction.

TABLE 4

Intercorrelations of Job Satisfaction and Personality Variables

\begin{tabular}{|l|c|c|c|c|c|c|c|}
\cline { 2 - 7 } \multicolumn{1}{c|}{} & $\begin{array}{c}\text { Ceneral Job } \\
\text { Satis faction }\end{array}$ & $\begin{array}{c}\text { Your } \\
\text { Job }\end{array}$ & $\begin{array}{c}\text { Your hork } \\
\text { Group }\end{array}$ & $\begin{array}{c}\text { Work Con- } \\
\text { ditions }\end{array}$ & $\begin{array}{c}\text { Super- } \\
\text { vision }\end{array}$ & $\begin{array}{c}\text { Policies \& } \\
\text { Practices }\end{array}$ & $\begin{array}{c}\text { Your Job } \\
\text { Perfomance }\end{array}$ \\
\hline Number checisd & 0,24 & 0,16 & 0,24 & 0,15 & 0,20 & 0,16 & 0,29 \\
Defensiveness & 0,27 & 0,19 & 0,26 & 0,12 & 0,22 & 0,17 & 0,32 \\
Favorable adjectives & $-0,29$ & $-0,18$ & $-0,29$ & $-0,13$ & $-0,24$ & $-0,20$ & $-0,32$ \\
Unfavorable adjectives & 0,18 & 0,13 & 0,16 & NS & 0,15 & NS & 0,25 \\
Self-Confidence & 0,13 & 0,09 & 0,18 & 0,11 & 0,18 & 0,12 & 0,15 \\
Self-Control & NS & NS & NS & NS & NS & NS & NS \\
Lability & 0,25 & 0,18 & 0,29 & 0,15 & 0,22 & 0,20 & 0,30 \\
Persoanl adjustment & 0,23 & 0,18 & 0,18 & NS & 0,18 & 0,09 & 0,27 \\
Achievement & 0,20 & 0,15 & 0,17 & NS & 0,14 & NS & 0,25 \\
Dominance & 0,21 & 0,18 & 0,28 & 0,14 & 0,21 & 0,12 & 0,28 \\
Endurance & 0,13 & 0,14 & 0,16 & 0,13 & 0,19 & 0,09 & 0,21 \\
Order & 0,13 & 0,11 & 0,16 & NS & 0,14 & 0,11 & 0,19 \\
Intraception & 0,25 & 0,13 & 0,24 & 0,10 & 0,19 & 0,18 & 0,23 \\
Nurturance & 0,30 & 0,18 & $n, 27$ & 0,14 & 0,21 & 0,16 & 0,27 \\
Affiliation & 0,10 & NS & NS & NS & NS & NS & 0,15 \\
Heterosexuality & NS & NS & NS & NS & NS & NS & 0,11 \\
Exhibition & NS & NS & $-0,12$ & $-0,11$ & $-0,15$ & $-0,12$ & NS \\
Autonony & $-0,15$ & NS & $-0,17$ & $-0,09$ & $-0,13$ & $-0,12$ & $-0,10$ \\
Aggression & NS & NS & NS & $-0,11$ & $-0,10$ & NS & NS \\
Change & $-0,22$ & $-0,12$ & $-0,22$ & NS & $-0,16$ & $-0,14$ & $-0,26$ \\
Succorance & $-0,16$ & $-0,11$ & $-0,12$ & NS & $-0,10$ & NS & $-0,21$ \\
Abasement & NS & NS & NS & NS & NS & NS & NS \\
Deference & $-0,12$ & NS & $-0,08$ & NS & NS & $-0,09$ & NS \\
\hline
\end{tabular}

All significant at $p<0,05$ level

NS = not signifficant

In general this study on the job satisfaction of dietitians tried to explain this complex phenomenon in terms of the interrelationships of personality, general job satisfaction and satisfaction with specific aspects of the job using existing scales as well as a Job Factor scale 
specifically developed for this group. A recent study by Shapiro and Stern (1975) on job satisfaction of male and female professional and non-professional employees, however, states that it may be misleading to attempt to explain job satisfaction of any group that was not measured by scales validated for that group. The results of this study on job satisfaction of professional dietitians may thus serve as a stimulus for further research on the job satisfaction of women in professions and perhaps lead to validation of appropriate measures.

\section{SUMMARY}

Research on the job satisfaction of a selected group of hospital dietitians is reported in an attempt to explain the interrelationship of various aspects contributing to such satisfaction. General job satisfaction, satisfaction with specific aspects of the job and personality profiles of a newly developed Job Factor scale. The study is a further contribution to the understanding of job satisfaction of professional women in a specific work environment - in this case professional dietitians in hospitals.

\section{REFERENCES}

Alexander, F.M.A. Job Preferences, Manifest Needs and Occupational Values of Freshman Student Nurses. Ph.D. thesis, Syracuse Univ., 1962.

Carroll, E. Job Satisfaction - A Review of Literature. Cornell, N.Y. State Schoo1 of Industrial and Labor Relations, 1969.

Cleveland, S.E. Personality characteristics of dietitians and nurses. Journal of American Dietetic Association. 1963, 43, 104-109.

Crites, J.O. Vocational Psychology. New York: MacGraw-Hill, 1969.

Gough, H.G. \& Heilburn, A.B. The Adjective Check List Manual. California. Consul. Psych. Press Inc., 1965.

Heilbrun, A.B. Further validation of the need scales: The order scale. Journal of Consulting Psychology. 1962, 26, 478.

Happock, R. Job Satisfaction. New York: Harper, 1935.

Hornaday, J.A. Interest patterns of dietitians. Journal of American Dietetic Association, 1963, 43, 99-103.

King, E.E. Relationships of Personal Value Systems to a Measure of Job Satisfaction among Personnel of the Florida Agricultural Extension. Ph.D. thesis, Univ. of Wisconsin, 1961.

Lewis, E.C. Developing Woman's Potential. Iowa: Iowa State Univ. Press, 1965.

McGibony, J.R. Principles of Hospital Administration. New York: Putnam's, 1969.

Porter, L.W. Job attitudes in management. Perceived deficiencies in need fulfillment as a function of job level. Journal of Applied Psychology, 1962, 46, 357. 
Shapiro, H.J. \& Stern, L.W. Job Satisfaction: Male and female, professional and nonprofessional. Personnel Journal, 1975, 54, 388-407.

Tansiongkun, V.C. Perceived Need Satisfactions and Importance of Needs of Hospital Dietitians. M.S. thesis, Univ. of Wisconsin, 1968.

Wagner, M.G. \& Dreyer, A.S. The dietitian's perception of authority. Journal of American Dietetic Association, 1961, 41, 205-216.

Walt, D.E. The Motivation for Women to Work in High Level Professional Positions. Ph.D. thesis, American University, 1962. 